\title{
EVALUATION OF PRODUCTIVITY AND IMPACT ON SOIL OF TRACKED PROSILVA F2/2 FORWARDER IN FOREST THINNING
}

\author{
Gatis Rozītis, Agris Zimelis, Andis Lazdiṇš \\ Latvian State Forest Research Institute 'Silava' \\ agris.zimelis@silava.lv
}

\begin{abstract}
Tracked forwarders is one of the solutions for the forest soils with poor bearing capacity providing ability to use well-known technology for reasonable cost to improve accessibility of forest resources. Tracked forwarders are not common in forest nowadays and only a few models are produced serially. The ProSilva F2/2 is a new middle-class forwarder, whose frontal tracks are replaced with big tires, ensuring large contact surface, increased mobility of the machine and significantly reduced mass without loosing the load capacity ( 15 tonnes). The aim of the study was to evaluate productivity, soil impact and cost of the roundwood forwarding using the ProSilva F2/2. The study was conducted in Finland. Productivity (time per crane cycle, split into operations and loads), load size, depth of ruts and soil compaction were estimated during the study.

According to the study results, the average productivity is $16 \mathrm{~m}^{3}$ per hour (driving distance to a landing site $200 \mathrm{~m}$, driving speed $2.8 \mathrm{~km} \mathrm{~h}^{-1}$, average load $9.7 \mathrm{~m}^{3}$ ). The productivity can be significantly increased by more efficient utilization of the load capacity and by using gripper with the tilt function. The length of ruts on peat soil $\left(56 \mathrm{~m} \mathrm{ha}^{-1}\right)$ do not exceed the permitted threshold values in Latvia. The compaction of soil took place mainly in topsoil, no changes in soil density were observed in deeper soil layers. The prime cost of forwarding according to the preliminary estimates is $2.5 € \mathrm{~m}^{-3}$ if the annual production is at least $62000 \mathrm{~m}^{3}$. Utilization rate is important to keep forwarding cost low.
\end{abstract}

Key words: tracked forwarder, productivity, forest thinning.

\section{Introduction}

According to the National Forest Inventory (NFI) data, the forest area in Latvia is 3.2 mill. ha, including 0.4 mill. ha of forests on drained organic soils and 0.3 mill. ha of forests on wet organic soils. Extreme forwarding conditions according to the national classification system can be an issue in $10 \%$ of the stands and bad forwarding conditions - in $33 \%$ of the stands. Reduction of the mature forest area on dry and drained mineral soils will worsen the forwarding conditions in future and will raise a question about significant changes in harvesting methods and selection of appropriate machinery in forestry to access the forest resources in areas with extreme forwarding conditions.

According to the Joint Stock Company 'Latvia's state forests' (JSC) data, bad and extreme forwarding conditions (estimated as a share of extracted roundwood) reached $28 \%$ in 2016 and it had increased by $2 \%$ in comparison to 2015 . Communication with the experts from JSC confirms that the share of the bad and extreme forwarding conditions will increase in future.

According to the NFI data about all felling sites where more than $10 \mathrm{~m}^{3} \mathrm{ha}^{-1}$ have been extracted during the last 5 years, extreme conditions can be an issue in $4 \%$ of stands and bad conditions - in 35\% of stands. These numbers do not include potentially bad or extreme forwarding conditions between a stand and roadside. Similar results (4\% of extreme conditions and $38 \%$ of bad conditions) were obtained if the clear-felling sites were evaluated separately. This result proves that the situation in private forests is considerably worse, especially in the share of bad forwarding conditions, than in state forests.

If extrapolated to the total forest area, the extreme forwarding conditions can be an issue in $10 \%$ of stands and bad forwarding conditions - in $33 \%$ of the forest stands. It means that in future forwarding conditions will worsen.

Damage to roots and stems, which is the primary result of bad or extreme forwarding conditions, can lead to fungal infection which can cause wood discoloration or even decay. The water regime and nutrition conditions in the forest soil can change as a result of soil settling (Ring et al., 2015). The operation of forest machines is therefore avoided during the period of high soil compaction or rut formation risk, and the harvesting is usually postponed to the winter when soil is normally frozen in extreme conditions. It is estimated that the seasonal variation in timber procurement can cause considerable losses; in Finland alone these losses are approximately $100 \mathrm{M} €$ annually (Pennanen \& Mäkelä, 2003). Forest operations in poor bearing conditions increase time and fuel consumption and decrease the efficiency of harvesting operations (Sirén et al., 2013).

Furthermore, deep ruts affect the general acceptability of the forest operations. The costs caused by extreme forwarding conditions could be decreased by additional information on soil conditions, especially soil bearing capacity. The load bearing capacity of soil is often described by its penetration resistance. Accordingly, forest operations could be planned to be performed during adequate bearing capacity or routed to avoid sections of poor 
bearing capacity, thus minimizing the damage and maximizing the efficiency of harvesting. Another alternative is use of tracked forwarders with a considerably smaller impact on soil in comparison to conventional wheeled forwarders (Edlund, Bergsten, \& Löfgren, 2016; Lupikis, Kaleja, \& Lazdins, 2015; Cambi et al., 2016).

The most popular forwarder model produced by ProSilva company up to now has been the fully tracked 15-4ST, which has been produced for more than 10 years. The $15-4 \mathrm{ST}$ forwarder is one of the largest and, at the same time, one of the most gentle forest machines, which can be used both for final felling and thinning on soils with low bearing capacity. In Latvia ProSilva 15-4 ST forwarder has been used both for thinning and final felling. It mostly transports wood from harvesting areas with long delivery roads, impassable for wheeled tractors, therefore forwarding costs of ProSilva are relatively high. The main advantages of ProSilva 15-4ST are stability on soils with low bearing capacity, which exceeds indicators of a standard wheeled forwarder several times, as well as the high load capacity (15 tonnes), which allows to reduce cumulative pressure on soil due to the reduction of number of passes in the same area and better distributed weight (Kaleja, Lazdins, \& Prindulis, 2015).

Studies on productivity and costs of ProSilva 15-4 ST were conducted in 2014, where this tractor was compared with the mid-sized forwarder John Deere 810 , equipped with chains on all axles or rear axles. In this study, the average time consumption for loading was 60 minutes, for unloading - 29 minutes, driving time - 17 minutes (the forwarding distance was $850 \mathrm{~m})$, the average load -8 tonnes $\left(9.6 \mathrm{~m}^{3}\right)$. Evaluation of the prime cost of forwarding proved that ProSilva forwarder is an economically viable option in areas with extreme forwarding conditions, and it is crucial that the main strip-road is not damaged by wheeled forwarders before it is used by the ProSilva (Kalēja, Lazdins, \& Zimelis, 2014b). The main drawback of ProSilva forwarder identified in the study was higher purchase costs. The main work method related issue was forwarding of assortments one by one, accordingly, the operators transported 1 or 2 assortments at once, thus considerably increasing the driving time and as a consequence - the impact on soil. Mixing of assortments in load is key to increasing productivity and reducing impact on soil using high capacity forwarders for thinning (Kalēja, Lazdins, \& Zimelis, 2014a).

In 2015, repeated trials with ProSilva 15-4 ST forwarder were conducted in a collaboration with 'Serviss Betta' Ltd. The aim of the trials was to investigate the actual fuel consumption of the forwarder and load size. Studies revealed that fuel consumption of the forwarder ProSilva 15-4 ST does not exceed that of wheeled tractors with analogue load capacity (14 L per hour on average). Under extreme conditions, when the wheeled tractor created ruts after a few drives, the tracked one could extract 5 times more timber before rut formation. It was highlighted in this study that ProSilva 15 4ST with a standard frame is unable to load 2 rows of $3 \mathrm{~m}$ long logs. Thus, if the dominant length of logs is $3 \mathrm{~m}$, the forwarder's capacity is always used insufficiently (Lazdiņš \& Zimelis, 2015).

In 2015 ProSilva company developed a modified forwarder prototype, the front chains of which were replaced with a pair of big tyres (width $75 \mathrm{~cm}$, height $150 \mathrm{~cm}$ ). The purpose of chain replacement was to decrease machine weight, as well as to improve its manoeuvrability and efficiency in long driving distances. Increased pressure on soil due to replacement tracks is compensated by large tyre surface and hydraulic balancing system, which allows to equalize pressure on front and rear axles as well as pressure on both sides of the machine. In order to increase track usage time, thickness of tracks is increased. Applications of the new forwarder model have not been studied so far; whereas productivity and influence on soil of the tracked model was assessed in several studies in Finland and Latvia, positioning this forwarder as currently the most advanced solution for the forwarding on organic soils. The scope of the study is to evaluate if the productivity, impact on soil and cost of the roundwood forwarding using the semi-tracked ProSilva F2/2 forwarder are sufficient for commercial application in Latvia in extreme forwarding conditions.

\section{Materials and Methods}

The study was conducted in 3 forest stands in Finland (LKS92 coordinates of the stand centroids 582477.135,926606.244; 582634.384,926143.535 and 582093.954,926369.467). The total area of experimental sites was 5.4 ha, the average tree height - 13.3-14.0 m, growing stock - 108-129, dominant tree species - spruce and birch. The tracked ProSilva forwarder model F2/2 with large wheels on the front axle was tested in the study. Detailed specifications of the machine are not yet available. Indicative specifications are provided in Table 1. In comparison to a fully tracked model, this forwarder is lighter, faster and more manoeuvring.

Detailed time studies split the work time into 15 operations (Table 2). Load size was determined according to the operator's estimate. Additional information obtained was reason for breaks, applied service works etc. Time study did not include preparation for work, which took about 1 hour. Duration of shifts was 8 hours. 
ProSilva forwarder specifications

\begin{tabular}{|c|l|l|}
\hline No. & \multicolumn{1}{|c|}{ Parameter } & \multicolumn{1}{c|}{ Values } \\
\hline 1. & Dimensions & $\begin{array}{l}\text { Length } 9317 \mathrm{~mm}, \text { width } 2800 \mathrm{~mm} \text {, clearance } 702 \mathrm{~mm} \text {, load capacity } 15 \text { tonnes, } \\
\text { empty weight about } 20 \text { tonnes }\end{array}$ \\
\hline 2. & Hydraulic system & Sensors to avoid overloading, engine capacity $190 \mathrm{~cm}^{3}$, hydrostatic transmission \\
\hline 3. & Engine & Iveco N67 ENT, capacity $175 \mathrm{~kW}$, torque $1020 \mathrm{Nm}$ at $1400 \mathrm{rpm}$ \\
\hline 4. & Loading space & Lenght $4000 \mathrm{~mm}$, loading area $4.5 \mathrm{~m}^{2}$ \\
\hline 5. & Crane & Kesla $800 \mathrm{~T}$ \\
\hline 6. & Tracks & $\begin{array}{l}\text { Rear }-75 \mathrm{~cm} \text { wide tracks with rounded edges to improve adherence, front } 75 \mathrm{~cm} \\
\text { wide tyres with chains }\end{array}$ \\
\hline
\end{tabular}

Table 2

Work operations in productivity studies

\begin{tabular}{|c|c|c|c|}
\hline Type of operation & No & Operation & Explanation \\
\hline \multirow[t]{14}{*}{ Productive time } & 1. & Drive in & Drive into the stand without load \\
\hline & 2. & Reach logs & Reach logs with crane \\
\hline & 3. & Grip & Grip logs with fork \\
\hline & 4. & Load in & Load logs into loading space \\
\hline & 5. & Rearrange load & Rearrange logs in loading space, put back fallen logs \\
\hline & 6. & Drive during loading in & Driving in stand during loading \\
\hline & 7. & Prepare road & Putting slash into strip-roads \\
\hline & 8. & Drive out & Driving out from the stand with load \\
\hline & 9. & Reach during loading out & Reaching logs with crane during loading out \\
\hline & 10. & Grip during loading out & Gripping of logs during loading out in loading space \\
\hline & 11. & Load out & Putting logs into assortments pile \\
\hline & 12. & Rearrange assortments & $\begin{array}{l}\text { Rearranging of landing yard (lining up of tops, putting } \\
\text { fallen logs into pile etc.) }\end{array}$ \\
\hline & 13. & Drive in landing area & Driving in landing area during loading out \\
\hline & 14. & Other operations & $\begin{array}{l}\text { Non-conventional operations (small repairs and service, } \\
\text { checking driving conditions etc.) }\end{array}$ \\
\hline Other work time & 15. & Break & $\begin{array}{l}\text { Time spent for non-work operations like eating, smoking } \\
\text { etc., excluding longer breaks like serious repairs when } \\
\text { engine is off }\end{array}$ \\
\hline
\end{tabular}

Harvesting was done with the tracked ProSilva S6 harvester. The number of produced assortments per stand - 2-3, mainly pulp wood, biofuel and small logs. Length of logs $-3-5 \mathrm{~m}$. Harvesting residues were left dispersed in the stand except wet areas where they were put into strip roads. Time studies were done for 2 operators who both had experience in thinning, but limited experience with tracked machines carefully using load capacity of the machine. Experienced operators would work with larger loads.

Weather conditions during the study were good, the average temperature $-20-25{ }^{\circ} \mathrm{C}$. Short rain falls (12 $\mathrm{mm}$ in total) were observed from 28 to 30 of June; heavy rain falls took place 2 weeks before the study (49 mm during 3 days).
The study was implemented in 2 sites with heavy forwarding conditions according to the contractor's decision: a stony site, where the rain did not affect forwarding, and peat soil (depth of peat more than $1 \mathrm{~m}$ ), where topsoil after raining was wet and bearing capacity considerably reduced. The relative soil moisture $(0-10 \mathrm{~cm}$ layer $)$ in peatland was $47 \%$ during the studies.

Prime cost estimates are based on earlier studies (Lazdiņš, Liepiņš, \& Zimelis, 2008; Lazdiņš \& Zimelis, 2015). Operational costs of the ProSilva cannot be estimated because the machine was in a prototype stage during the trial, therefore the operational costs estimated earlier for a fully tracked version were used in the calculation (Kalēja \& Lazdin̄š, 2014; Kalēja 
et al., 2014; Lazdiņš et al., 2016). Fuel consumption was determined using the machine accounting system. Salaries were assumed according to the average salary range of the forest machine operators published by the State Tax Service. It was assumed in the calculation that the forwarder would work for 20000 hours.

\section{Results and Discussion}

The total amount extracted in the study was $145 \mathrm{~m}^{3}$. The average load was $9.1 \mathrm{~m}^{3}$, significantly bigger loads $\left(9.7 \mathrm{~m}^{3}\right)$ in peatland. The productive time per load in peatland was 36 minutes and in the stony site it was twice more (75 minutes). The average driving speed was $2.8 \mathrm{~km} \mathrm{~h}^{-1}$. The average productivity in peatland was $2.9 \mathrm{~min} . \mathrm{m}^{-3}$. Due to the relatively high proportion of time spent to pick and move assortments into load ( $46 \%$ of the total loading time in comparison to $32 \%$ using tractor equipped with the tilt function, Lazdin̄š et al., 2016), it was concluded that considerable increase of productivity can be reached by using tilt function in the crane so that logs can be moved in vertical position. Smaller dimension of logs in the stony site considerably decreased the productivity of loading. The main productivity figures are provided in Table 3.

Assuming that forwarder is taking only full loads (12 $\mathrm{m}^{3}$ according to the conditions in experimental sites), productivity in peatland would increase by $4 \%$ and in stony site - by $12 \%$. In real conditions the increase of productivity could be higher with full loads because of reduced time consumption for driving. Load capacity of the machine is about $15 \mathrm{~m}^{3}$. In Latvia the most of assortments produced in thinning are pulpwood ( $3 \mathrm{~m})$, firewood (2 to $3 \mathrm{~m}$ ) and small logs (up to $4.2 \mathrm{~m}$ ). Considering the structure of assortments, it is reasonable to increase the tractor frame length to $5 \mathrm{~m}$ to be able to load 2 parcels of short (up to $3 \mathrm{~m}$ ) assortments.

The number of mechanically damaged remaining trees is considerably high $(4.9 \%$ on average in both sites) and corresponds to the average data obtained in Latvia in early thinning (Kaleja, Lazdins, \& Prindulis, 2015). The number of stem damages can be reduced by using the tilt function during forwarding, by more careful harvesting and by putting slash into striproads in the turning areas. Length of ruts in peatland in extreme forwarding conditions is $56 \mathrm{~m} \mathrm{ha}^{-1}$, in stony site - twice less.
The scope of measurement of the soil penetration resistance on peatland was to compare forwarding conditions with other trials implemented earlier in Latvia (Kalēja \& Lazdiņš, 2014; Prindulis, Kalēja, \& Lazdinš, 2016). The soil penetration resistance in trials implemented in Latvia on soft soil with wheeled forwarder equipped with wide tracks was at topsoil level $(11-20 \mathrm{~cm}) 1.1$ to $1.3 \mathrm{MPa}$ after forwarding of 5 loads ( 35 to $39 \mathrm{~m}^{3}$ ), and the length of ruts did not exceed the limiting threshold values. The trials in Latvia were done in dry conditions, however it was considered that the conditions are not suitable for wheeled forwarder. In the study implemented in Finland, the soil penetration resistance on strip-roads on a peatland after forwarding of 4 to 5 loads was $0.26 \mathrm{MPa}$ and did not increase significantly in deeper soil layers. It means that the soil penetration resistance in the study site on peatland is considerably smaller than in earlier studies in Latvia and the results are not actually comparable. But the relatively small amount of ruts still demonstrates that the ProSilva F2/2 is very efficient on peat soils. A significant impact on soil penetration resistance due to compaction was found in the stony area, however the compaction was found only in the upper $20 \mathrm{~cm}$ layer in contrast to the studies with wheeled forwarders, demonstrating considerable compaction in deeper soil layers - down to $80 \mathrm{~cm}$ (Prindulis, Kalēja, \& Lazdiņš, 2016). It should be noted that measurement conditions were not favourable in the study in Finland (a lot of stones in soil), therefore the accuracy of measurement results in deeper soil layers may be affected by limited measurement data, and for accurate comparison the measurements should be repeated on stone free sites.

The new model of semi-tracked ProSilva forwarder is not yet in conventional use, therefore operational costs can only be assumed according to the results obtained with a fully tracked model, which are verified by operational costs of a tracked excavator in Latvia. Real operational costs will be available when the machines start to work in production. One of the most important cost positions is tracks, which can heavily affect the average hourly cost.

Forwarding costs at $200 \mathrm{~m}$ forwarding distance and 4320 productive work hours per year are $2.5 € \mathrm{~m}^{-3}$ (over bark), the total costs of harvesting, forwarding and road transport to $50 \mathrm{~km}$ distance are $14 € \mathrm{~m}^{-3}$

The main productivity figures

Table 3

\begin{tabular}{|l|l|l|l|l|l|}
\hline Study site & $\begin{array}{c}\text { Loading in, } \mathrm{m}^{3} \text { per } \\
\text { productive hour }\end{array}$ & $\begin{array}{c}\text { Loading out, } \mathrm{m}^{3} \text { per } \\
\text { productive hour }\end{array}$ & $\begin{array}{c}\text { Productivity, } \mathrm{m}^{3} \text { per } \\
\text { productive hour }\end{array}$ & $\begin{array}{c}\text { Share of } \\
\text { productive time }\end{array}$ & $\begin{array}{c}\text { Loads per } \\
\text { productive hour }\end{array}$ \\
\hline Stony area & 11 & 42 & 6 & $82 \%$ & 0.8 \\
\hline Peatland & 28 & 82 & 16 & $83 \%$ & 1.7 \\
\hline
\end{tabular}


Logging costs in specified conditions in peatland

Table 4

\begin{tabular}{|l|l|l|l|}
\hline \multicolumn{1}{|c|}{ Parameter } & \multicolumn{1}{c|}{ Harvester } & Forwarder & Roundwood truck \\
\hline Annual cost, $€$ & $€ 85679$ & $€ 56723$ & $€ 30464$ \\
\hline Investments & $€ 60928$ & $€ 40516$ & $€ 33204$ \\
\hline Personnel & $€ 122129$ & $€ 67338$ & $€ 72900$ \\
\hline Operational costs & $€ 13437$ & $€ 8229$ & $€ 6828$ \\
\hline Profit margin & $€ 282173$ & $€ 172805$ & $€ 143395$ \\
\hline Total & \multicolumn{3}{l}{} \\
\hline Productivity & 8.5 & 16.0 & 9.1 \\
\hline Productivity, $\mathrm{m}^{3}$ per productive hour & 44364 & 69162 & 32475 \\
\hline Annual production, $\mathrm{m}^{3}$ & \multicolumn{2}{l}{} \\
\hline Cost & $€ 7.07$ & $€ 2.50$ & $€ 4.42$ \\
\hline Roundwood under-bark, $€ \mathrm{~m}^{-3}$ & \multicolumn{3}{l|}{} \\
\hline
\end{tabular}

(Table 4). Lifetime and replacement costs of tracks are taken from a heavy (16 tonnes) excavator. The ProSilva F2/2 forwarder can extract 69 thousand $\mathrm{m}^{3}$ of roundwoovārds pārvietotsd annually. The productivity of forwarder is about $30 \%$ higher in comparison to harvester productivity in stands with similar dimensions of extracted trees according to earlier studies in Latvia (Kaleja \& Lazdins, 2014; Skudra et al., 2015); thus, in thinning the harvester and forwarder can work as a pair and ProSilva forwarder can simultaneously do additional tasks, such as forwarding of roundwood from intermediate storages over soils with weak bearing capacity. In the final felling the difference in productivity will decrease.

The sensitivity analysis of forwarding costs includes forwarding distance, load size, fuel consumption, fuel price, forwarding distance and number of productive hours per year. Forwarding distance has a considerable impact on the costs - if the forwarding distance increases to $1200 \mathrm{~m}$, forwarding cost increases to $5.42 € \mathrm{~m}^{-3}$ (2.2 times). An increase of forwarding distance would have an even bigger impact in bad forwarding conditions when the forwarder should prepare the road and drive slowly. The situation when a tracked forwarder is used on a road with deep ruts left by a wheeled forwarder would have an even more harmful effect on forwarding cost. Size of load also has a significant impact on forwarding cost, especially when the forwarding distance is increasing. If the average load size increased to $11 \mathrm{~m}^{3}$, forwarding cost would decrease to $2.27 € \mathrm{~m}^{-3}$; if the load size decreased to $5 \mathrm{~m}^{3}$, forwarding cost would increase to $4.54 € \mathrm{~m}^{-3}$ (by $45 \%$ in comparison to average results in the study). Fuel consumption and fuel price (considering the range of fuel prices during last 2 years) have a relatively small impact on the forwarding cost. The most significant impact on it has the number of productive hours per year. If the number of productive time decreases below 1300 hours, forwarding cost increases by 2.5

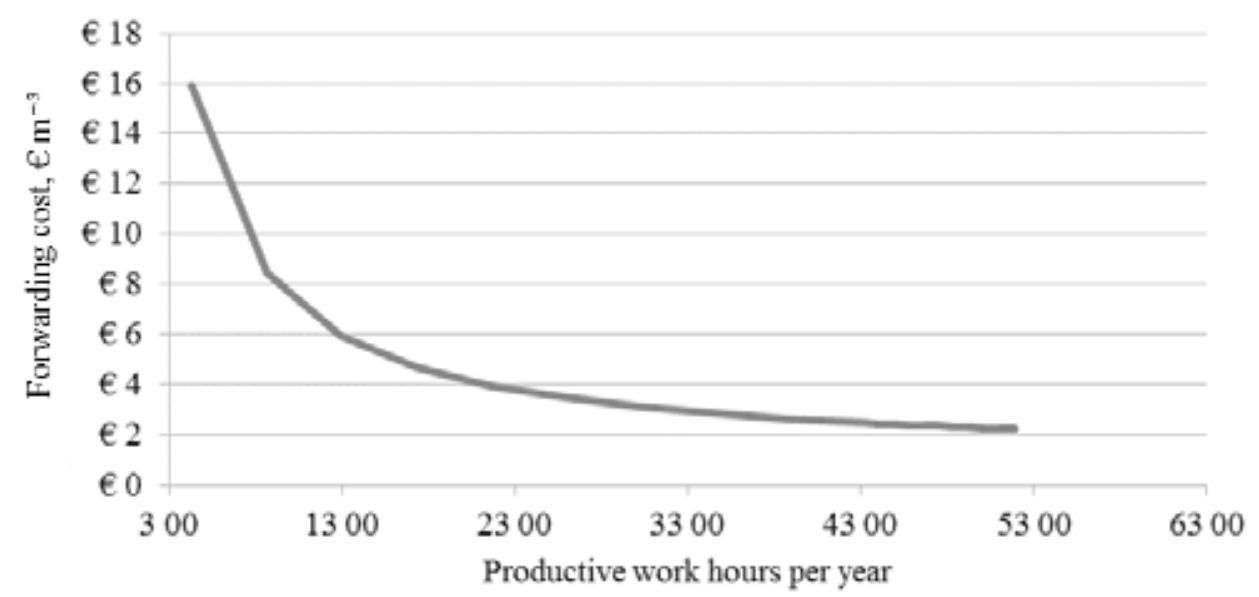

Figure 1. Sensitivity analysis of forwarding cost depending on utilization rate. 
times, and rapidly grows if the number of productive hours continues to decrease (Figure 1). In practice, the increase of forwarding cost due to the reduction of productive time might not be so steep, because the calculation assumes that operators keep a constant salary regardless of the worked hours. However, if the reason for reduction of productive time is service, forwarding cost can increase even steeper.

There is limited experience with the ProSilva F2/2 forwarder to compare forwarding cost with the conventional wheeled machines, especially because the wearing of tracks, as well as schedule and costs of other service operations, are not yet known. The study proves that the machine can be used in extreme forwarding conditions where conventional wheeled machines cannot work at all, and productivity figures are as good as for a conventional wheeled machine in normal forwarding conditions. This means that the machine can be competitive if the operational costs are not too high and the machine is utilized to full extent. The optimal utilization rate is 4000 hours (or at least 2000) hours annually.

The estimates of prime costs of forwarding, obtained in the study, should be considered as preliminary information due to the fact that operational costs and durability of the machine were not evaluated in real life conditions during the study period. Therefore, the economic assessment, including prime costs, should be evaluated in separate studies, when more production data are available. The most critical issues are the wearing of tracks, average load size and time spent on maintenance and repairs.

\section{Conclusions}

1. The length of ruts even in extreme conditions normally harvested only when the soil is frozen do not exceed the threshold values for thinning in Latvia. In many cases, the reason for the formation of ruts was an inappropriate operation of the tracked harvester, which often drove off the strip road, thus damaging soil and stems of the remaining trees in the turning places, and putting slash into small piles in the centre of strip-road instead of putting them below tracks.

2. The annual productive time has the most significant impact on the forwarding cost, therefore planning of utilization of the machine is very important. The optimal number of working hours annually is 4000, minimum is about 2000 hours. Alternative uses, for example, ash spreading on peat soils, should be considered in order to increase the machine utilization rate.

3. According to the study results, the ProSilva F2/2 forwarder is suitable for extraction of biofuel and roundwood in extreme forwarding conditions on a peat soil, where wheeled forwarders cannot be used even with auxiliary tracks on all axles. To increase the load capacity, forwarder with a prolonged frame $(5 \mathrm{~m})$ should be used in Latvia instead of one with a standard frame.

\section{Acknowledgements}

The study was implemented within the scope of the JSC funded research project 'Research program on forest biofuel and mechanization of forest operations' (agreement No 5-5.9_003v_101_16_47).

\section{References}

1. Cambi, M., Laschi, A., Certini, G., Fabiano, F., Foderi, C., \& Picchio, R. (2016). Impact of wheeled and tracked tractors on soil physical properties in a mixed conifer stand. iForest - Biogeosciences and Forestry [online], pp. 863 - 868. Retrieved August 31, 2016, from: http://www.sisef.it/iforest/ contents/?id=ifor1382-008.

2. Edlund, J., Bergsten, U., \& Löfgren, B. (2012). Effects of two different forwarder steering and transmission drive systems on rut dimensions. Journal of Terramechanics [online]. Retrieved August 31, 2016, from: http://www.sciencedirect.com/science/article/pii/S0022489812000304.

3. Kalēja, S., \& Lazdiņš, A. (2014). Evaluation of impact on assortments's structure on productivity of Timbear harvester in early thinning. Proceedings of Nordic Baltic Conference OSCAR14 Solutions for Sustainable Forestry Operations, 2014. pp. $58-60$.

4. Kaleja, S., Lazdins, A., \& Prindulis, U. (2015). Evaluation of impact of different types of tracks on productivity and cost of differently equipped forwarders in thinning, Proceedings of Adaptation and mitigation: strategies for management of forest ecosystems. pp. $41-43$.

5. Kaleja, S., Lazdins, A., \& Zimelis, A. (2014a). Impact of assortiments' structure on harvesting productivity and costs of pre-commercial thinning, Research for Rural Development. International Scientific Conference Proceedings. pp. $83-90$.

6. Kalēja, S., Lazdiņš, A., \& Zimelis, A. (2014b). Plastmasas ķēžu pielietošanas izmēginājumi kokmateriālu pievešanā krājas kopšanā, ziņojums (Application of composite tracks in roundwood forwarding from commercial thinning, research report). Salaspils. 37 p. (in Latvian).

7. Lazdiņš, A., Liepiņš, J., \& Zimelis, A. (2008). Pievešanas apstākḷu ietekme uz pievešanas maš̄̄nu izmaksām galvenās izmantošanas cirtēs - augsnes sablīvēšanās mērījumu rezultāti (Impact of forwarding conditions 
on forwarding cost in final felling - results of measurement of soil compaction). LVMI Silava. 24 p. (in Latvian).

8. Lazdiņš, A., Prindulis, U., Kalēja, S., Daugaviete, M., \& Zimelis, A. (2016). Productivity of Vimek 404 T5 harvester and Vimek 610 forwarder in early thinning. Agronomy Research, 14(2), pp. 475 - 484.

9. Lazdiňš, A., \& Zimelis, A. (2015). ProSilva 15-4ST pievedējtraktora degvielas patēriña un kravnesības novērtējums krājas kopšanas cirtēs (Evaluation of fuel consumption and load capacity of tracked forwarder ProSilva 15-4ST, research report). Salaspils. 3 p. (in Latvian).

10. Lupikis, A., Kaleja, S., \& Lazdins, A. (2015). Impact of tracked and wheeled forest machines on soil penetration resistance in early thinning, Proceedings of Adaptation and mitigation: strategies for management of forest ecosystems. pp. $43-44$.

11. Pennanen, O., \& Mäkelä, O. (2003). Metsätehon raportti. Tech. Rep. 153. [online], Retrieved August 31, 2016, from: http://www.metsateho.fi/wp-content/uploads/2015/02/metsatehon_raportti_153.pdf.

12. Prindulis, U., Kalēja, S., \& Lazdiņš, A. (2016). Soil compaction in young stands during mechanized logging of biofuel and roundwood assortments. Research for Rural Development. pp. $69-75$.

13. Ring, E., Högbom, L., Nohrstedt, H.-Ö., \& Jacobson, S. (2015). Soil and soil-water chemistry below different amounts of logging residues at two harvested forest sites in Sweden. Silva Fennica [online], 49(4). Retrieved February 28, 2017, from: http://www.silvafennica.fi/article/1265.

14. Sirén, M., Ala-Ilomäki, J., Mäkinen, H., Lamminen, S., \& Mikkola, T. (2013). Harvesting damage caused by thinning of Norway spruce in unfrozen soil. International Journal of Forest Engineering, 24(1), pp $60-75$.

15. Skudra, A., Kaleja, S., Prindulis, U., \& Lazdins, A. (2015). Influence of work method on harvester productivity in thinning of coniferous stands, Proceedings of Adaptation and mitigation: strategies for management of forest ecosystems. pp. $57-61$. 